\title{
Neo-adjuvant hormone therapy for non-metastatic prostate cancer: a systematic review and meta-analysis of 5,194 patients
}

\author{
Jimeng Hu, Hua Xu, Wenhui Zhu, Fei Wu, Jianqing Wang, Qiang Ding and Haowen Jiang*
}

\begin{abstract}
Background: Neo-adjuvant hormone therapy (NHT) following radical prostatectomy (RP) or radiotherapy has been utilized in the multimodal approach to patients with intermediate- to high-risk prostate cancer (PCa). Herein, we performed a systematic review and meta-analysis of published randomized trials to evaluate the clinical efficacy of NHT.

Methods: Literatures were searched from PubMed, EMBASE, Web of Science, and Cochrane Library for comparing neo-adjuvant therapy group (NHT plus radiotherapy or radical prostatectomy) with traditional therapy (radiotherapy or prostatectomy) alone. Quality of the research was assessed on the basis of the Cochrane's risk of bias of randomized controlled trial. Comparable information were obtained from eligible trials and assembled for meta-analysis up to 31 August 2014. RevMan 5.2 software was used for statistical analysis.

Results: Fifteen randomized controlled trials (RCTs) (total 5,194 patients) were included in this study. Meta-analysis showed there was a significant improvement in overall survival (OS) (Odds ratio (OR) $=1.51,95 \%$ confidence interval (Cl) 1.22 to $1.87, P=0.0002$ ), positive surgical margin (PSM) rate $(\mathrm{OR}=0.30,95 \% \mathrm{Cl} 0.24$ to $0.38, P<0.00001)$, and biochemical disease-free survival (bDFS) $(\mathrm{OR}=1.95,95 \% \mathrm{Cl} 1.13$ to $3.39, P=0.02)$, but no significant difference in disease-free survival $(\mathrm{OR}=1.52,95 \% \mathrm{Cl} 0.90$ to $2.59, P=0.12)$ and clinical disease-free survival (cDFS) $(\mathrm{OR}=0.96$, $95 \% \mathrm{Cl} 0.22$ to $4.18, P=0.95$ ). Heterogeneity and risk of bias were observed between different studies.
\end{abstract}

Conclusions: Patients with aggressive prostate cancer would better benefit from the receipt of neo-adjuvant therapy. Physicians should make individualized treatment strategies according to adverse reactions, financial capacities, and personal wishes.

Keywords: Prostate cancer, Neo-adjuvant hormone therapy, Radiotherapy, Prostatectomy, Meta-analysis

\section{Background}

Currently, prostate cancer ( $\mathrm{PCa}$ ) is considered to be one of the most common cancers in Western countries [1]. With the widespread use of prostate-specific antigen (PSA) screening and the development of imaging technology, PCa incidence rates have been increasing rapidly in Asian countries, especially, in developed metropolitan areas [2]. Radical radiotherapy (RT) or radical prostatectomy (RP) integrated with neo-adjuvant hormone therapy (NHT) has been utilized in multimodal treatment in patients with intermediate- to high-risk PCa.

\footnotetext{
*Correspondence: haowenj73@126.com

Department of Urology, Huashan Hospital, Fudan University, No.12

WuLuMuQi Middle Road, 200040 Shanghai, People's Republic of China
}

One of the reasons why NHT is recommended for patients in all risk groups is that it can shrink prostate volume before RT or RP, thereby reducing the radiation dose to critical organs or tissue injury during operation and leading to a safer and more thorough treatment [3]. NHT plus RT or RP was found to have better efficacy than traditional therapy (radiotherapy or surgery alone) in some randomized controlled trials (RCTs), especially, in patients with intermediate- or high-risk PCa [4-6].

In trials of NHT prior to RT, specific indicators such as overall survival (OS), distant metastasis, biochemical disease-free survival (bDFS), and biochemical failure 
were all significantly improved compared to RT alone $[7,8]$. In patients receiving NHT before RP, pathological down-staging and positive surgical margin (PSM) rates were obviously improved in certain trials [9], but this did not lead to an improvement in OS and disease-free survival (DFS) $[10,11]$.

The purpose of the present study was to determine treatment efficacy in patients who had received NHT prior to RT or RP (which is considered the first-line treatment for $\mathrm{PCa}$ ), by performing a systematic review and meta-analysis of RCTs in men with non-metastatic $\mathrm{PCa}$. In this way, we aimed to conclusively establish whether either of the treatment strategies benefited these PCa patients.

\section{Methods}

\section{Literature search}

This study does not involve human subjects and does not require Institutional Review Board review or consent. Articles were gathered by searching the following databases: PubMed, EMBASE, Web of Science, and Cochrane Library. In addition, abstracts and presentations were collected through major academic conferences, such as American Society of Clinical Oncology
(ASCO), European Society for Medical Oncology (ESMO), and Federation of European Cancer (FEC). Furthermore, we searched the reference lists of reviews and RCTs to find potentially eligible literature. The deadline for the literature search was 31 August 2014.

We used the following MeSH terms integrated with free terms in all the search strategies: prostate cancer, neo-adjuvant hormone therapy, radiotherapy, prostatectomy, review, meta-analysis, systematic review, randomized, phase III. Only articles published in English were selected. When the study outcomes were inexplicit or more details were required, we contacted the corresponding author to obtain the original data.

\section{Trial identification criteria}

The inclusion criteria, based on the PICO principles, are as outlined below.

(1) Participants (P): All patients who were diagnosed with non-metastatic $\mathrm{PCa}$ on cytological and pathological examination were eligible to be recruited to this systematic review. The nationality and race were not restricted. None of the patients had any severe concomitant disease.

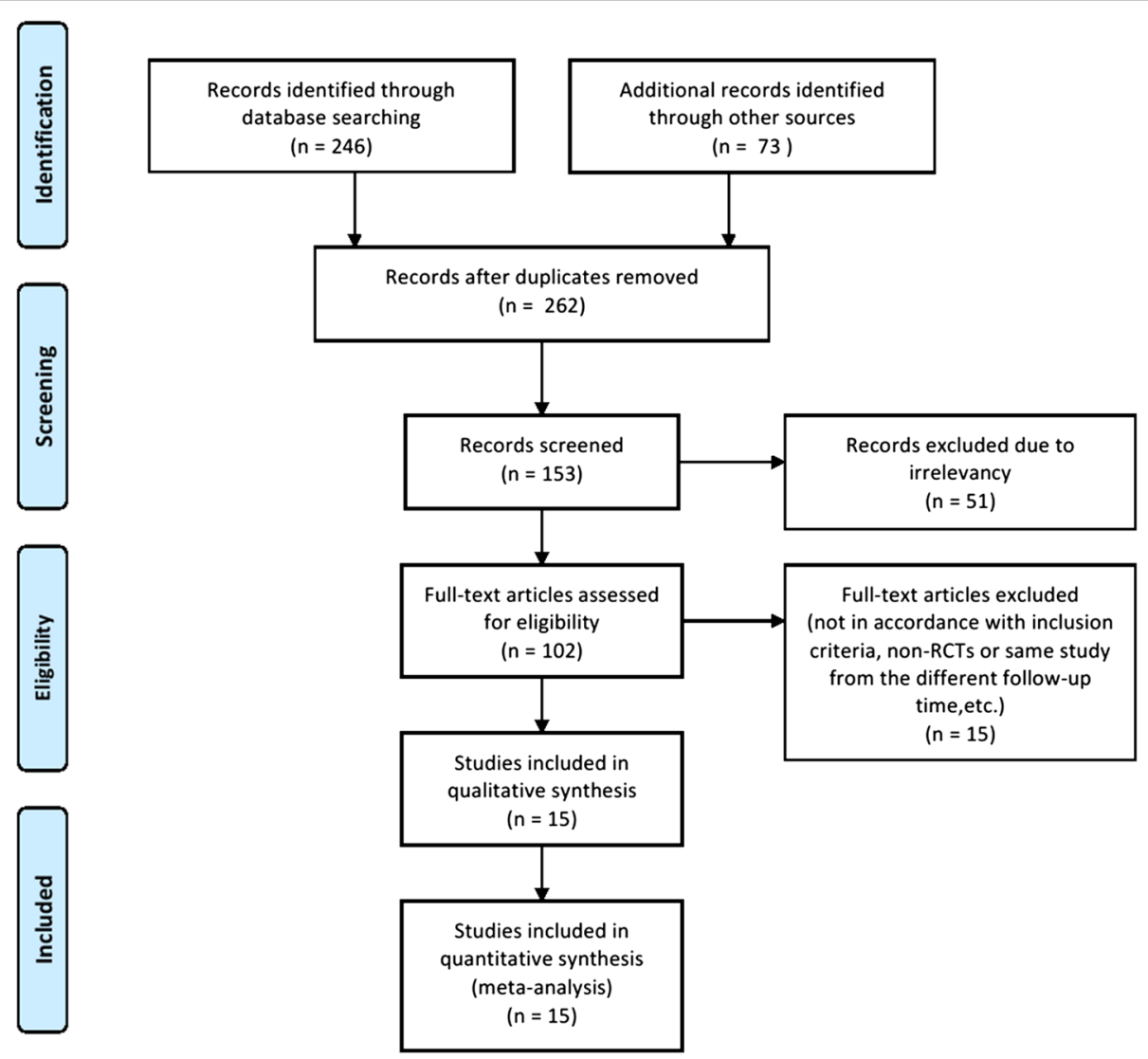

Figure 1 Flow diagram illustrated the process of the study selection for the meta-analysis. 
(2) Interventions (I) and comparisons (C): RCTs that analyzed neo-adjuvant therapy (NHT prior to RT or RP) versus traditional therapy (RT or RP alone) in nonmetastatic PCa patients, in order to compare the clinical results, including efficacy and safety, between two the groups were eligible.

(3) Outcomes (O): We included studies that compared the indicators OS, PSM, and DFS rates between the NHT plus RP group and the RP only group; and OS, bDFS, and clinical disease-free survival (cDFS) rates between the NHT plus RT group versus the RT only group.

We excluded articles if (1) the study design was not a RCT (for example, retrospective study, cohort study, and case reports), (2) the study was not an original article (for example, letters, reviews), and (3) the therapeutic effect was insufficient to obtain useful information.

\section{Data extraction}

The information extracted from each study included the following: first author's name, time of publication, patient characteristics, sample size, and outcomes. Data extraction was independently performed by three investigators $(\mathrm{Hu}, \mathrm{Xu}$, and $\mathrm{Zhu})$. Two of the investigators $(\mathrm{Hu}$ and $\mathrm{Xu}$ ) evaluated the quality of the original research by means of the Cochrane Collaboration quality checklist for RCTs, and disagreements between them were resolved by consensus.

\section{Data analysis}

Survival rate was used as a binary variable in all the included studies. Therefore, the log of the odds ratio (OR) and the $95 \%$ confidence interval (CI) were reckoned as the effect size for each considered endpoint.

Table 1 Pretreatment characteristics of patients included in systematic review

\begin{tabular}{|c|c|c|c|c|c|}
\hline Author & $\begin{array}{l}\text { Sample size } \\
\text { (ntg/ttg) }\end{array}$ & Age (years) (ntg/ttg) & PSA level (ng/ml) (ntg/ttg) & Clinical stage (ntg/ttg) & Gleason score (ntg/ttg) \\
\hline Pilepich 2001 [12] & $226 / 230$ & No record & No record & T2 to 4 & $\begin{array}{l}2 \text { to } 6 \text { (total: } 129), \\
7 \text { (total: } 176), \\
8 \text { to } 10 \text { (total: } 124)\end{array}$ \\
\hline Laverdiere 2004 [13] & $149 / 154$ & Median: 69/68 & Median: 9.3/12 & $\begin{array}{l}\text { T2 (total: } 255 \text { ), } \\
\text { T3 (total: } 40 \text { ) }\end{array}$ & $\begin{array}{l}\leq 6 \text { (total: } 223) \\
7 \text { to } 10 \text { (total: } 77 \text { ) }\end{array}$ \\
\hline Soloway 1995 [14] & $149 / 154$ & $\begin{array}{l}\text { Mean: } \\
64.9 \pm 5.7 / 65.4 \pm 5.9\end{array}$ & Median: 14.3/12.5 & T2b, NxM0 & Mean: $6.1 \pm 0.17 / 5.8 \pm 0.16$ \\
\hline Denham 2005 [15] & $270,272 / 276$ & Median: 68, 68/67 & Median: 14.4, 14.6/16.4 & $\begin{array}{l}\text { T2b }(66,68 / 72), \\
\text { T2c }(88,94 / 92), \\
\text { T3 to } 4(111,105 / 106)\end{array}$ & $\begin{array}{l}2 \text { to } 6(117,122 / 113), \\
7(92,99 / 114) \\
8 \text { to } 10(53,43 / 41)\end{array}$ \\
\hline Roach 2008 [5] & $224 / 232$ & Median: 70/71 & Median: 22.6/33.8 & T2 to 4 & $\begin{array}{l}3 \text { to } 6(70 / 59), \\
7 \text { to } 10(145 / 156)\end{array}$ \\
\hline Deham 2011 [6] & $265,267 / 270$ & Median: 68, 68/67 & Median: 14.4, 14.5/16.4 & $\begin{array}{l}\text { T2b }(67,68 / 72), \\
\text { T2c }(87,94 / 92) \\
\text { T3 to } 4(111,105 / 106)\end{array}$ & $\begin{array}{l}2 \text { to } 6(118,123 / 114) \text {, } \\
7(94,101 / 115) \\
8 \text { to } 10(53,43 / 41)\end{array}$ \\
\hline Dalkin 1996 [16] & $30 / 31$ & Median: 65.5/64.7 & $\begin{array}{l}4.1 \text { to } 10(16 / 18), 10.1 \text { to } \\
20(9 / 9),>20(3 / 1)\end{array}$ & $\begin{array}{l}\text { T1c }(17 / 16), \text { T2a }(8 / 12), \\
\text { T2b (3/0) }\end{array}$ & $\begin{array}{l}2 \text { to } 4(8 / 6), 5 \text { to } 7(16 / 21) \text {, } \\
8 \text { to } 10(4 / 1)\end{array}$ \\
\hline Goldenberg 1996 [17] & $112 / 101$ & $\begin{array}{l}\text { Mean: } \\
62.5 \pm 6.0 / 62.2 \pm 5.9\end{array}$ & $\begin{array}{l}0 \text { to } 4(10 / 13), 4.1 \text { to } \\
10(45 / 41), 10.1 \text { to } 25(33 / 30), \\
25.1 \text { to } 50(13 / 7)\end{array}$ & $\begin{array}{l}\text { T1b (5/4), T1c (5/3), } \\
\text { T2a (30/33), T2b (19/17), } \\
\text { T2c (42/34) }\end{array}$ & $\begin{array}{l}2 \text { to } 4(2 / 5), 5 \text { to } 7(82 / 75), \\
8 \text { to } 10(15 / 11)\end{array}$ \\
\hline Labrie 1997 [18] & $71 / 90$ & Range: 46 to 72 & $\leq 10(67 / 53),>10(23 / 18)$ & $\begin{array}{l}\text { BO (3/3), B1 (43/39), } \\
\text { B2 (29/17), C1 (8/7), C2 (7/5) }\end{array}$ & No record \\
\hline Schulman 2000 [9] & 192/210 & No record & No record & T2 (105/115), T3 (87/95) & No record \\
\hline Selli 2002 [19] & $143,122 / 128$ & $\begin{array}{l}\text { Mean: } \\
65.43,66.16 / 65.72\end{array}$ & Median: 10.15, 10.0/10.20 & $\mathrm{T} 2$ to $3, \mathrm{NO}, \mathrm{MO}$ & $\begin{array}{l}2 \text { to } 6(29,2 / 46), 7(31,8 / 1) \text {, } \\
8 \text { to } 10(0,11 / 0)\end{array}$ \\
\hline Soloway 2002 [20] & $149 / 154$ & Mean: 64.9/65.4 & Median: 14.3/12.5 & $\mathrm{T} 2 \mathrm{~b}$ & Mean: $6.1 / 5.8$ \\
\hline Aus 2002 [21] & $63 / 63$ & Mean: 67/66 & Median: 12.0/11.2 & $\begin{array}{l}\text { T1b to T1c }(10 / 15), \\
\text { T2a }(10 / 10), \text { T2b to } \\
\text { T3a }(43 / 38)\end{array}$ & $\begin{array}{l}2 \text { to } 4(2 / 1), 5 \text { to } 6(26 / 22) \text {, } \\
7 \text { to } 10(35 / 40)\end{array}$ \\
\hline Klotz 2003 [10] & $112 / 101$ & Median: 64/63 & $\begin{array}{l}<10(61 / 54), 10 \text { to } \\
20(32 / 26),>20(17 / 18)\end{array}$ & $\begin{array}{l}\text { T1b to T1c }(12 / 7), \\
\text { T2a }(36 / 35), T 2 b(19 / 21), \\
\text { T2c }(41 / 32)\end{array}$ & $\begin{array}{l}2 \text { to } 6(75 / 73), 7(21 / 17), \\
8 \text { to } 10(14 / 8)\end{array}$ \\
\hline Prezioso 2004 [22] & $91 / 93$ & Mean: 64.9/64.5 & $\begin{array}{l}<4 \text { (ntg:6), } \geq 4<10 \text { (ntg: } 30) \\
\geq 10 \text { (ntg: } 39)\end{array}$ & T1a to T2b & No record \\
\hline
\end{tabular}




\begin{tabular}{|c|c|c|c|c|c|}
\hline Author & Inclusion criteria & Exclusion criteria & Dose (NHT) & Interventions & $\begin{array}{l}\text { Follow-up } \\
\text { time }\end{array}$ \\
\hline $\begin{array}{l}\text { Pilepich } \\
2001[12]\end{array}$ & $\begin{array}{l}\text { Tumor size was measured by the surface area } \\
\text { palpable by rectal examination. Performance } \\
\text { score (KPS) }=60 \text { positive lymph nodes if below } \\
\text { the common iliac level }\end{array}$ & $\begin{array}{l}\text { Patients with involved common } \\
\text { peri-aortic or iliac lymph node }\end{array}$ & $\begin{array}{l}2 \text { months goserelin acetate ( }(3.6 \mathrm{mg} \\
\text { every } 4 \text { weeks) flutamide ( } 250 \mathrm{mg} \text { tid) }\end{array}$ & $\begin{array}{l}\text { NHT followed by RT and continued } \\
\text { during RT versus RT alone. Pelvis: } 44 \\
\text { to } 46 \text { Gy, Prostate: } 65 \text { to } 70 \text { Gy, } 33 \\
\text { fractions/ } 6.5 \text { weeks }\end{array}$ & $\begin{array}{l}\text { Median: } \\
6.7 \text { years }\end{array}$ \\
\hline $\begin{array}{l}\text { Laverdiere } \\
2004[13]\end{array}$ & $\begin{array}{l}\text { Age }<75 \text { years, PSA }<50 \mathrm{mg} / \mathrm{ml} \text {, without bone } \\
\text { metastases }\end{array}$ & $\begin{array}{l}\text { No previous hormonal therapy or } \\
\text { chemotherapy }\end{array}$ & $\begin{array}{l}3 \text { months leuprolide ( } 7.5 \text { mg monthly) } \\
\text { flutamide ( } 250 \mathrm{mg} \text { tid) }\end{array}$ & $\begin{array}{l}\text { NHT followed by RT versus RT alone. } \\
\text { Pelvis: } 64 \text { Gy, } 32 \text { fractions/ } 6.5 \text { weeks }\end{array}$ & $\begin{array}{l}\text { Median: } \\
3.7 \text { years }\end{array}$ \\
\hline $\begin{array}{l}\text { Soloway } \\
1995[14]\end{array}$ & $\begin{array}{l}\text { Age }<75 \text { years, PSA }<50 \mathrm{ng} / \mathrm{ml} \text {, normal bone } \\
\text { scan }\end{array}$ & $\begin{array}{l}\text { No previous hormonal therapy or } \\
\text { chemotherapy }\end{array}$ & $\begin{array}{l}2 \text { weeks leuprolide ( } 7.5 \mathrm{mg} \text { monthly) } \\
\text { flutamide ( } 250 \mathrm{mg} \text { tid) }\end{array}$ & NHT followed by RP versus RP alone & $\begin{array}{l}\text { Median: } \\
\text { unknown }\end{array}$ \\
\hline $\begin{array}{l}\text { Denham } \\
2005[15]\end{array}$ & $\begin{array}{l}\text { No bone metastases, prostatic acid } \\
\text { phosphatase }<1.8 \mathrm{u} / \mathrm{ml} \text {, PSA }<50 \mathrm{ng} / \mathrm{ml}\end{array}$ & $\begin{array}{l}\text { Renal dysfunction, hepatic disease, } \\
\text { other malignancies or concomitant } \\
\text { anti-androgenic medication }\end{array}$ & $\begin{array}{l}3 \text { months cyproterone acetate }(300 \mathrm{mg} \\
\text { daily for } 12 \text { weeks), } 6 \text { months } \\
\text { cyproterone acetate }\end{array}$ & $\begin{array}{l}3 \text { or } 6 \text { months NHT followed by RT } \\
\text { versus RT alone. Prostate/seminal } \\
\text { vesicles: } 66 \text { Gy, } 33 \text { fractions/ } 6.5 \text { to } 7 \text { weeks }\end{array}$ & $\begin{array}{l}\text { Median: } \\
5.9 \text { years }\end{array}$ \\
\hline $\begin{array}{l}\text { Roach } 2008 \\
\text { [5] }\end{array}$ & $\begin{array}{l}\text { bulky }(5 * 5 \mathrm{~cm}) \text { tumors, with or without pelvic } \\
\text { lymph node involvement }\end{array}$ & no follow-up data & $\begin{array}{l}2 \text { months flutamide ( } 250 \mathrm{mg} \text { tid), } \\
\text { goserelin ( } 3.6 \text { mg every } 4 \text { weeks) }\end{array}$ & $\begin{array}{l}\text { NHT followed by RT versus RT alone. } \\
\text { Regional lymphatics: } 44 \text { to } 46 \text { Gy } \\
\text { prostate: } 65 \text { to } 70 \mathrm{~Gy}\end{array}$ & $\begin{array}{l}\text { Median: } \\
11.9 \text { years }\end{array}$ \\
\hline $\begin{array}{l}\text { Deham } \\
2011[6]\end{array}$ & Histologically confirmed, informed consent & $\begin{array}{l}\text { Significant intercurrent medical } \\
\text { conditions, prior malignancies or } \\
\text { metastases }\end{array}$ & $\begin{array}{l}\text { Goserelin ( } 3.6 \mathrm{mg} \text { given subcutaneously } \\
\text { every month), flutamide ( } 250 \mathrm{mg} \text { tid) }\end{array}$ & $\begin{array}{l}3 \text { or } 6 \text { months NHT followed by RT } \\
\text { versus RT alone. Prostate and seminal } \\
\text { vesicles: } 66 \text { Gy, } 33 \text { fractions/ } 6.5 \text { to } 7 \text { weeks }\end{array}$ & $\begin{array}{l}\text { Median: } \\
10.6 \text { years }\end{array}$ \\
\hline $\begin{array}{l}\text { Dalkin } 1996 \\
{[16]}\end{array}$ & PSA $>4.0 \mathrm{ng} / \mathrm{ml}$, projected survival $>10$ years & No record & 3 months goserelin (s.c 3.6 mg monthly) & NHT followed by RP versus RP alone. & $\begin{array}{l}\text { Median: } \\
\text { unknown }\end{array}$ \\
\hline $\begin{array}{l}\text { Goldenberg } \\
1996[17]\end{array}$ & $\begin{array}{l}\text { Histologically confirmed, prostatic acid } \\
\text { phosphatase }<1.8 \mathrm{u} / \mathrm{ml} \text {, PSA }<50 \mathrm{ng} / \mathrm{ml}\end{array}$ & $\begin{array}{l}\text { Renal dysfunction, hepatic disease, } \\
\text { other malignancies or concomitant } \\
\text { anti-androgenic medication }\end{array}$ & $\begin{array}{l}\text { Cyproterone acetate ( } 300 \mathrm{mg} \text { daily for } \\
12 \text { weeks) }\end{array}$ & NHT followed by RP versus RP alone & $\begin{array}{l}\text { Median: } \\
\text { unknown }\end{array}$ \\
\hline $\begin{array}{l}\text { Labrie } 1997 \\
{[18]}\end{array}$ & $\begin{array}{l}\text { Histologically confirmed, life expectancy } \\
>10 \text { years }\end{array}$ & No record & $\begin{array}{l}3 \text { months flutamide and leuprolide } \\
\text { acetate }\end{array}$ & NHT followed by RP versus RP alone & $\begin{array}{l}\text { Median: } \\
\text { unknown }\end{array}$ \\
\hline $\begin{array}{l}\text { Schulman } \\
2000[9]\end{array}$ & Histologically confirmed, PSA $<100 \mathrm{ng} / \mathrm{ml}$ & No record & $\begin{array}{l}3 \text { months goserelin ( } 3.6 \mathrm{mg} \\
\text { subcutaneously depot injection each } \\
\text { month) flutamide ( } 250 \mathrm{mg} \text { tid) }\end{array}$ & NHT followed by RP versus RP alone & $\begin{array}{l}\text { Median: } \\
4.0 \text { years }\end{array}$ \\
\hline $\begin{array}{l}\text { Selli } 2002 \\
{[19]}\end{array}$ & Histologically confirmed, informed consent & No record & $\begin{array}{l}\text { Goserelin ( } 3.5 \mathrm{mg} \text { subcutaneously depot } \\
\text { injection each month) bicalutamide } \\
\text { ( } 50 \mathrm{mg} / \text { day) }\end{array}$ & $\begin{array}{l}3 \text { or } 6 \text { months NHT followed by RP } \\
\text { versus RP alone }\end{array}$ & $\begin{array}{l}\text { Median: } \\
\text { unknown }\end{array}$ \\
\hline $\begin{array}{l}\text { Soloway } \\
2002[20]\end{array}$ & $\begin{array}{l}\text { Age }<75 \text { years, PSA }<50 \mathrm{ng} / \mathrm{ml} \text {, normal } \\
\text { bone scan }\end{array}$ & $\begin{array}{l}\text { No previous hormonal therapy or } \\
\text { chemotherapy }\end{array}$ & $\begin{array}{l}3 \text { months leuprolide ( } 7.5 \mathrm{mg} \text { monthly) } \\
\text { flutamide ( } 250 \mathrm{mg} \text { tid) }\end{array}$ & NHT followed by RP versus RP alone & $\begin{array}{l}\text { Median: } \\
5.0 \text { years }\end{array}$ \\
\hline $\begin{array}{l}\text { Aus } 2002 \\
{[21]}\end{array}$ & $\begin{array}{l}\text { Previously untreated, age }<75 \text { years, life } \\
\text { expectancy }>10 \text { years }\end{array}$ & Positive lymph nodes & $\begin{array}{l}3 \text { months triptorelin ( } 3.75 \text { mg i.m. } \\
\text { monthly) }\end{array}$ & NHT followed by RP versus RP alone & $\begin{array}{l}\text { Median: } \\
82 \text { months }\end{array}$ \\
\hline $\begin{array}{l}\text { Klotz } 2003 \\
{[10]}\end{array}$ & $\begin{array}{l}\text { Histologically confirmed, prostatic acid } \\
\text { phosphatase }<1.8 \mathrm{u} / \mathrm{ml} \text {, PSA }<50 \mathrm{ng} / \mathrm{ml}\end{array}$ & $\begin{array}{l}\text { Renal dysfunction, hepatic disease, } \\
\text { other malignancies or concomitant } \\
\text { anti-androgenic medication }\end{array}$ & $\begin{array}{l}3 \text { months cyproterone acetate ( } 300 \mathrm{mg} \\
\text { daily for } 12 \text { weeks) }\end{array}$ & NHT followed by RP versus RP alone & $\begin{array}{l}\text { Median: } \\
6.0 \text { years }\end{array}$ \\
\hline $\begin{array}{l}\text { Prezioso } \\
2004[22]\end{array}$ & $\begin{array}{l}\text { Lifespan }>5 \text { years, WHO performance status } \\
\text { up to } 2 \text {, no evidence of metastases, informed } \\
\text { consent }\end{array}$ & $\begin{array}{l}\text { No previous hormonal therapy or } \\
\text { chemotherapy, no previous } \\
\text { orchidectomy or other malignancies }\end{array}$ & $\begin{array}{l}3 \text { months leuprolide }(3.75 \mathrm{mg}) \\
\text { cyproterone acetate }(300 \mathrm{mg} \text { daily for } \\
3 \text { weeks) }\end{array}$ & NHT followed by RP versus RP alone & $\begin{array}{l}\text { Median: } \\
\text { unknown }\end{array}$ \\
\hline
\end{tabular}


The chi-square test and $I^{2}$ test were applied to detect statistical heterogeneity across trials. If heterogeneity was not present $\left(P>0.10, I^{2}<50 \%\right)$, the fixed-effects model would be selected for further analysis; otherwise, the random-effects model would be adopted.

The OR and $95 \%$ CI results could be divided into the following: (a) OR $>1$ and $95 \%$ CI not containing 1, survival rate was significantly higher in the combined therapy group than in the traditional therapy group; (b) $\mathrm{OR}<1$ and $95 \% \mathrm{CI}$ not containing 1 , survival rate was significantly higher in the traditional therapy group; (c) $\mathrm{OR}=1$, no difference in the failure rates of the two groups; and (d) 95\% CI containing 1, statistically insignificant difference in the failure rates of the two groups. All statistical analyses were performed using RevMan 5.2 software.

\section{Results}

\section{Study selection outcomes and quality assessment}

The search strategy identified 102 possible studies from all the databases. After we eliminated studies according to the exclusion criteria, 15 papers were considered relevant to this review. The detailed literature screening process has been presented in a flowchart (Figure 1).

A total of 5,194 PCa patients were included in this study, 2,907 and 2,287 in the neo-adjuvant therapy group and traditional therapy group, respectively. The follow-up duration was not exactly the same in the included studies, but in most studies, follow-up was performed for at least 3.7 years. The pretreatment (baseline) characteristics of the patients were similar in the two groups (Table 1). The characteristics of each trial have been summarized in Table 2 .

Although all the included studies were RCTs, only three mentioned the procedure of randomization. Two were randomized mainly on the basis of phone calls $[10,16]$, and one was randomized by the minimization technique after stratification [6]. Only one study mentioned the number and causes of dropouts and withdrawals [13]. None of the trials described the procedures used to evaluate the results or blind the allocation of interventions.

\section{Overall survival}

Five studies evaluated OS in the neo-adjuvant therapy group compared with the traditional therapy group. Since no heterogeneity was found among these studies $\left(P=0.49, I^{2}=0 \%\right)$, a fixed-effects model was selected for data analysis. The outcomes suggested that OS was significantly longer in the neo-adjuvant therapy group than in the traditional therapy group (OR $=1.51,95 \% \mathrm{CI}: 1.22$ to $1.87, P=0.0002$; Figure 2).

Disease-specific survival was presented in two of the above studies $[9,21]$ and showed no obvious improvement with neo-adjuvant therapy (relative risk $=1.00,95 \%$ CI: 0.98 to $1.03, P=0.77$ ).

\section{Positive surgical margin rate}

Nine RCTs assessed the PSM rates. No obvious heterogeneity was observed between these studies $(P=0.18$, $I^{2}=30 \%$ ), so a fixed-effects model was applied to analyze the effect size. The PSM rate was significantly lower in the neo-adjuvant therapy group than in the traditional therapy group $(\mathrm{OR}=0.30,95 \% \mathrm{CI}: 0.24$ to $0.38, P<$ 0.00001; Figure 3).

Positive lymph node involvement was found in five trials $[9,10,16,20,22]$, and the outcome was less frequent in the neo-adjuvant therapy group (relative risk $=0.66,95 \%$ CI: 0.47 to $0.94, P=0.02$ ).

\section{Disease-free survival}

Six RCTs reported DFS rates, and significant heterogeneity was detected among them $\left(P<0.00001, I^{2}=84 \%\right)$. Hence, a random-effects model was chosen. There was no significant difference between the neo-adjuvant therapy group and the traditional therapy group in terms of DFS $(\mathrm{OR}=1.52,95 \%$ CI: 0.90 to $2.59, P=0.12$; Figure 4 ).

One study [22] attempted to assess the efficacy of NHT on PSA relapse and pathological variables in contrast with prostatectomy alone, and defined PSA relapse based on the available data. However, the median followup time ( $<7$ months) was too short to meet the study requirements, and thus, the information was regarded as insufficient to accomplish the statistical analysis.

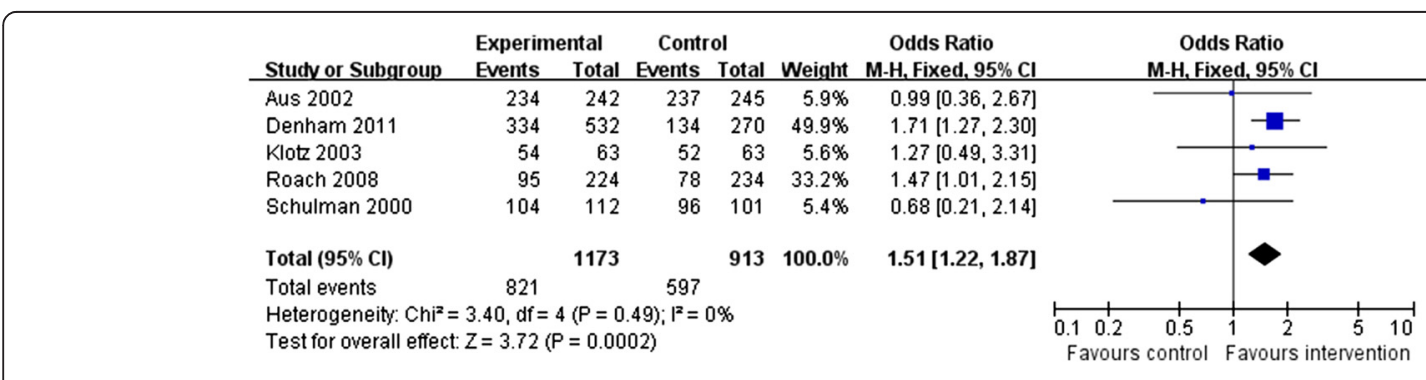

Figure 2 Meta-analysis of overall survival compared neo-adjuvant therapy group versus traditional therapy group. 


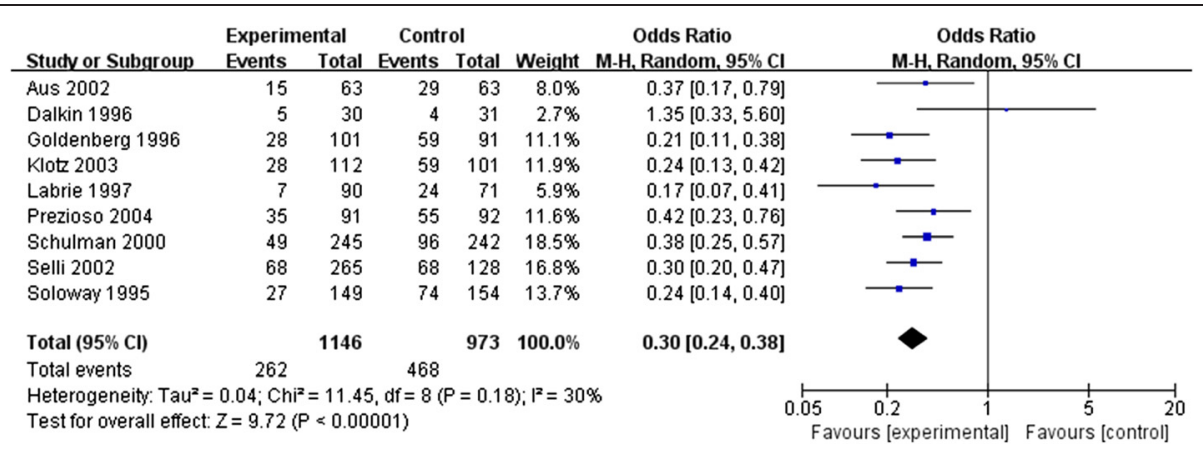

Figure 3 Meta-analysis of positive surgical margin rate compared neo-adjuvant therapy group versus traditional therapy group.

\section{Biochemical disease-free survival}

Three RCTs examined bDFS rates. Due to apparent heterogeneity between two of these studies $\left(P=0.05, I^{2}=\right.$ $66 \%)$, a random-effects model was adopted. In the neoadjuvant therapy group, bDFS was significantly increased compared with that in the traditional therapy group $(\mathrm{OR}=1.95,95 \% \mathrm{CI}: 1.13$ to $3.39, P=0.02$; Figure 5$)$.

Specifically, Pilepich et al. [12] reported the 8-year bDFS rates in the treatment (24\%) and control arms (10\%, $P<0.0001)$. Laverdiere et al. [13] found that the 7 year bDFS was significantly higher in the neo-adjuvant treatment arm than in the control arm $(P=0.009)$. Denham et al. [15] reported a significant improvement in the 5 -year bDFS in the neo-adjuvant therapy group $(P=$ 0.002).

\section{Clinical disease-free survival}

Two RCTs of 1,258 PCa patients evaluated cDFS rates in this meta-analysis. Significant heterogeneity was detected between the two studies $\left(P=0.09, I^{2}=65 \%\right)$, and so, a random-effects model was applied. No significant difference was observed with respect to cDFS between the two groups $(\mathrm{OR}=0.96,95 \% \mathrm{CI}$ : 0.22 to $4.18, P=$ 0.95; Figure 6).

\section{Discussion}

Two meta-analyses have assessed the use of neoadjuvant therapy for localized PCa $[23,24]$, but the trial identification criteria and primary endpoints in these articles are different from ours. Our research demonstrated a sufficient assessment of the clinical outcomes in the neo-adjuvant therapy group compared with the traditional therapy group, in patients with non-metastatic PCa.

Although the number of relevant studies was not enough to provide a reliable scientific basis, the clinical outcomes presented herein strengthen the role of NHT combined with RT or RP for non-metastatic PCa.

\section{Primary disclosures}

The results from the statistical analyses demonstrated that OS, PSM, and bDFS rates were significantly improved in the neo-adjuvant therapy group. These positive results suggested that NHT could considerably improve pathological outcomes and biochemical recurrence indicators such as PSM rate and serum PSA level. This shows that these treatment outcomes, which include pathological and biochemical indicators, are effective alternatives for efficacy evaluation. However, there was no significant difference in DFS and cDFS rates between the two groups in this systematic review. Considering the prognostic factors for systemic progression, Stewart et al. [25] found that the Gleason grading system indicates the risk of systemic progression in patients treated with prostatectomy after NHT.

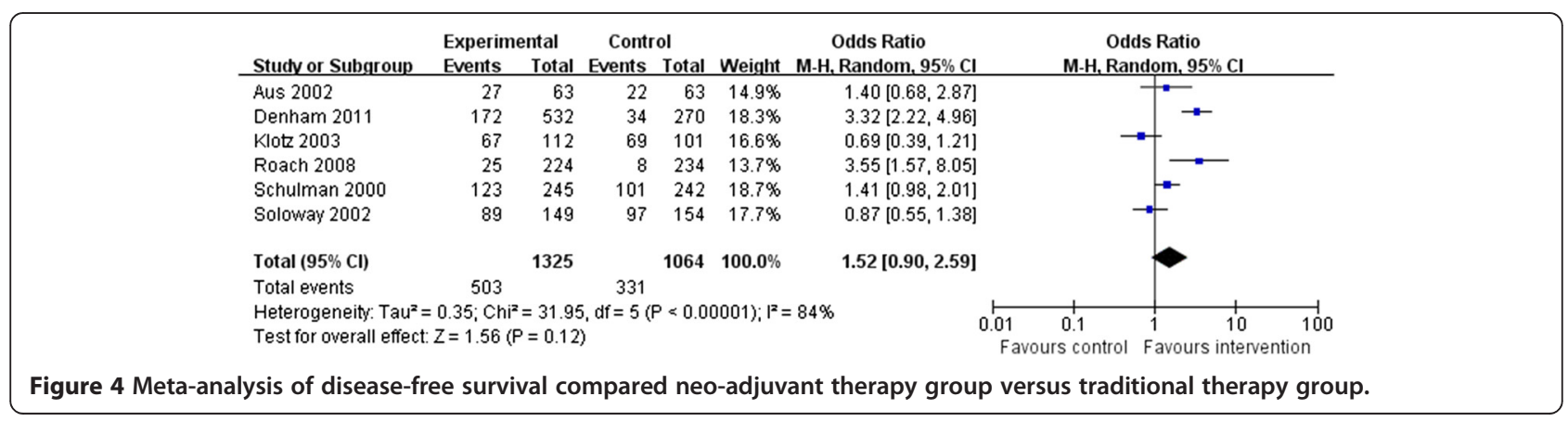




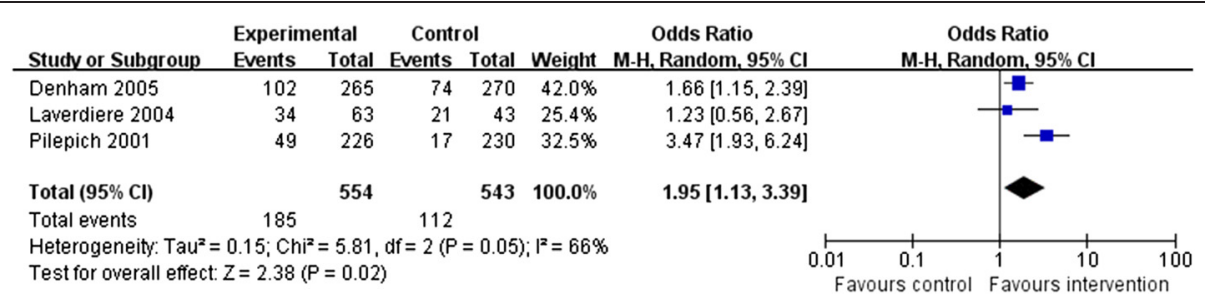

Figure 5 Meta-analysis of biochemical disease-free survival compared neo-adjuvant therapy group versus traditional therapy group.

Comprehensive statistical analysis revealed obvious heterogeneity between most individual studies. In our opinion, the heterogeneity may be attributable to the following factors: different types and doses of drugs, deviation in hormone allocation, definitions of biochemical recurrence, and variations in patient characteristics and follow-up duration. For instance, Laverdiere et al. [13] defined biochemical recurrence as two consecutive increases in serum PSA level of at least 1.0 and $\geq 1.5 \mathrm{ng} /$ $\mathrm{ml}$, according to the Vancouver rules. In contrast, Denham et al. [15] used the Houston method, which defines biochemical failure as increases in PSA level of $2 \mathrm{ng} / \mathrm{ml}$ or more above the post-treatment nadir measure.

This meta-analysis demonstrated that neo-adjuvant therapy plus RP or RT was associated with longer OS compared with RP or RT alone, in the overall combination therapy group as well as in each combination treatment subgroup. Furthermore, the benefits of neoadjuvant therapy plus RP or RT included a significant enhancement of loco-regional control in patients with non-metastatic, intermediate- to high-risk PCa.

The disaggregated analysis of different risk groups indicated that the superiority of neo-adjuvant therapy was most manifest in patients with high-risk PCa. However, the clinical significance of these outcomes is restricted by the use of different risk categories among the studies. The reliability of our preliminary findings will be verified by the results of further targeted studies in this specific area.

\section{Risk of bias evaluation}

Since about half of the researches had not offered sufficient evidence to verify whether the risk of bias in the trial identification criteria and randomization measures was low or high, the quality of evidence analyzed in this review varied.

Furthermore, it was unclear whether the outcome inspectors had been blinded to the group information in all the studies, and some authors failed to report all meaningful results, so the outcomes may be subject to reporting bias, with missing information potentially leading to an overvaluation of the observed effects.

\section{Limitations and prospects}

The survival analyses presented in the published articles tended to support NHT in combination with RP or RT. However, many uncertainties still exist. Although OS was obviously improved in these trials, which is a tangible clinical outcome and an apparent superiority of the regimen, the value of prolonged bDFS remains uncertain and may not translate into certain survival benefit. Owing to a 'duration of risk' effect, it seemed that $\mathrm{PCa}$ patients must survive for more than 7 years to benefit from the combined treatment. All the RCTs included in this meta-analysis were from Western countries rather than Asia. Thus, whether these outcomes can be extrapolated to Asian patients must be verified by further research.

Therapeutic benefit and side effects should be balanced by evidence-based adoption of the current information. The various indicators that need to be noted include $\mathrm{PCa}$ grade, risk group division, sexuality, life expectancy, physical function, and endocrine/metabolic status (including hypertension, adiposity, and diabetes mellitus).

Luteinizing hormone-releasing hormone agonist (LHRHa) analogues were applied in most neo-adjuvant setting trials, and the role of peripheral anti-androgens is still unclear. Newly developed drugs acting through androgen

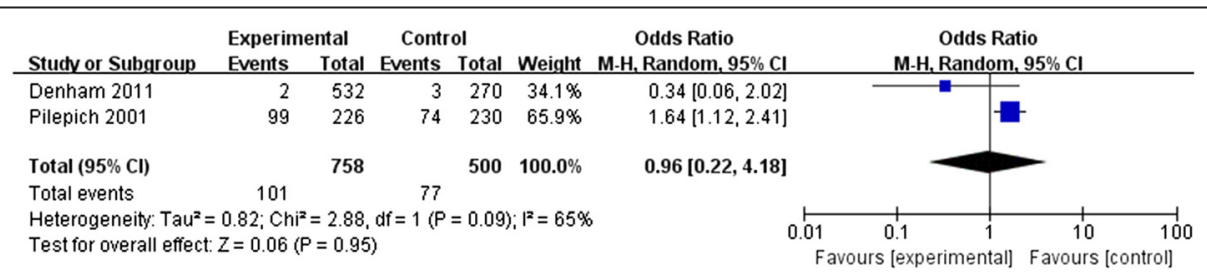

Figure 6 Meta-analysis of clinical disease-free survival compared neo-adjuvant therapy group versus traditional therapy group. 
suppression, such as enzalutamide and abiraterone, will play an important role in the future. Similarly, these drugs are considered to offer more effective androgen deprivation against prostate tumor cells, but whether they can lead to an obvious therapeutic benefit, such as tumor growth control and/or toxicity reduction, requires further comprehensive and systematic research. A recently published RCT [26] illustrated that LHRHa plus abiraterone acetate (AA) treatment could suppress tissue androgens more effectively than LHRHa alone. Thus, intensive intratumoral androgen suppression with LHRHa plus AA before RP may reduce tumor burden in patients with localized high-risk PCa.

In addition, the above agents should be assessed with regard to quality of life, adverse effects, and medical burden to the patients, these parameters could not be subjected to correlation analysis in this review. Physicians should make reasonable treatment strategies for PCa patients according to the patients' physical conditions, financial capacities, and personal wishes.

\section{Conclusions}

The outcomes of this meta-analysis indicated that patients with intermediate- to high-risk PCa would benefit more from NHT plus RT/RP than from RT/RP alone, although several limitations need to be addressed due to the small number of studies included.

Adverse reactions, medical costs during NHT, and other objective limitations will affect the treatment process significantly. Thus, physicians have to consider all these issues when formulating individualized treatment strategies.

\footnotetext{
Abbreviations

AA: abiraterone acetate; ASCO: American Society of Clinical Oncology; bDFS: biochemical disease-free survival; BF: biochemical failure; C: comparisons; cDFS: clinical disease-free survival; Cl: confidence intervals; DFS: disease-free survival; DM: distant metastasis; ESMO: European Society for Medical Oncology; FEC: Federation of European Cancer; I: interventions; LHRHa: luteinizing hormone-releasing hormone agonist; $\mathrm{NHT}$ : neo-adjuvant hormone therapy; O: outcomes; OR: odds ratio; OS: overall survival; P: participants; PCa: prostate cancer; PSA: prostate-specific antigen; PSM: positive surgical margin; RCTs: randomized controlled trials; RP: radical prostatectomy; RT: radical radiotherapy.
}

\section{Competing interests}

The authors declare that they have no competing interests.

\section{Authors' contributions}

$J M H$ and $\mathrm{HX}$ drafted the manuscript. WHZ, FW, and JQW assisted with manuscript preparation. JMH, XH, and $\mathrm{WHZ}$ extracted the data from the articles. QD and HWJ revised the manuscript. All authors have read and approved the final manuscript.

\section{Acknowledgements}

This work was collectively supported by grant 81272835 from the National Natural Science. The funders had no role in study design, data collection and analysis, decision to publish or preparation of the manuscript.

Received: 15 October 2014 Accepted: 9 February 2015

Published online: 22 February 2015

\section{References}

1. Siegel R, Naishadham D, Jemal A. Cancer statistics. CA Cancer J Clin. 2012;62(1):10-29.

2. Hsing AW, Tsao L, Devesa SS. International trends and pat-terns of prostate cancer incidence and mortality. Int J Cancer. 2000;85(1):60-7.

3. Kumar S, Shelley M, Harrison C, Coles B, Wilt TJ, Mason MD. Neo-adjuvant and adjuvant hormone therapy for localised and locally advanced prostate cancer. Cochrane Database Syst Rev. 2006;18(4):CD006019.

4. Hanks GE, Pajak TF, Porter A, Grignon D, Brereton H, Venkatesan V, et al. Phase III trial of long-term adjuvant androgen deprivation after neoadjuvant hormonal cytoreduction and radiotherapy in locally advanced carcinoma of the prostate: the Radiation Therapy Oncology Group protocol 92-02. J Clin Onol. 2003;21(21):3972-8.

5. Roach 3rd M, Bae K, Speight J, Wolkov HB, Rubin P, Lee RJ, et al. Short-term neoadjuvant androgen deprivation therapy and external-beam radiotherapy for locally advanced prostate cancer: long-term results of RTOG 8610. J Clin Oncol. 2008;26(4):585-91.

6. Denham JW, Steigler A, Lamb DS, Joseph D, Turner S, Matthews J, et al. Short-term neoadjuvant androgen deprivation and radiotherapy for locally advanced prostate cancer: 10-year data from the TROG 96.01 randomised trial. Lancet Oncol. 2011;12(5):451-9.

7. Laverdière J, Gomez JL, Cusan L, Suburu ER, Diamond P, Lemay M, et al. Beneficial effect of combination hormonal therapy administered prior and following external beam radiation therapy in localized prostate cancer. Int J Radiat Oncol Biol Phys. 1997;37(2):247-52

8. Lawton CA, Winter K, Murray K, Machtay M, Mesic JB, Hanks GE, et al. Updated results of the phase III Radiation Therapy Oncology Group (RTOG) trial 85-31 evaluating the potential benefit of androgen suppression following standard radiotherapy for unfavorable prognosis carcinoma of the prostate. Int J Radiat Oncol Biol Phys. 2001;49(4):937-46.

9. Schulman CC, Debruyne FM, Forster G, Selvaggi FP, Zlotta AR, Witjes WP. 4-year follow-up results of a European prospective randomised trial on neoadjuvant hormonal therapy prior to radical prostatectomy in T2-2N0M0 prostate cancer. Eur Urol. 2000;38(6):706-13.

10. Klotz LH, Goldenberg SL, Jewett MA, Fradet Y, Nam R, Barkin J, et al. Longterm follow up of a randomised trial of 0 versus 3 months of neoadjuvant androgen ablation before radical prostatectomy. J Urol. 2003;170(3):791-4.

11. Van Poppel H, De Ridder D, Elgamal AA, Van de Voorde W, Werbrouck P, Ackaert $\mathrm{K}$, et al. Neoadjuvant hormonal therapy before radical prostatectomy decreases the number of positive surgical margins in stage T2 prostate cancer: interim results of a prospective randomized trial. The Belgian Uro-Oncological Study Group. J Urol. 1995;154(2 Pt 1):429-34.

12. Pilepich MV, Winter K, John MJ, Mesic JB, Sause W, Rubin P, et al. Phase III radiation oncology group (RTOG) trial 86-10 of androgen deprivation adjuvant to definitive radiotherapy in locally advanced carcinoma of the prostate. Int J Rad Oncol Biol Phys. 2001;50(5):1243-52.

13. Laverdière J, Nabid A, De Bedoya LD, Ebacher A, Fortin A, Wang CS, et al. The efficacy and sequencing of a short course of androgen suppression on freedom from biochemical failure when administered with radiation therapy for T2-T3 prostate cancer. J Urol. 2004;171(3):1137-40.

14. Soloway MS, Sharifi R, Wajsman Z, McLeod D, Wood Jr DP, Puras-Baez A. Randomized prospective study comparing radical prostatectomy alone versus radical prostatectomy preceded by androgen blockade in clinical stage B2 (T2bNxM0) prostate cancer. The Lupron Depot Neoadjuvant Prostate Cancer Study Group. J Urol. 1995;154(2 Pt 1):424-8.

15. Denham JW, Steigler A, Lamb DS, Joseph D, Mameghan H, Turner S, et al. Trans-Tasman Radiation Oncology Group: short-term androgen deprivation and radiotherapy for locally advanced prostate cancer: results from the Trans-Tasman Radiation Oncology Group 96.01 randomised controlled trial. Lancet Oncol. 2005;6(11):841-50.

16. Dalkin BL, Ahmann FR, Nagle R, Johnson CS. Randomized study of neoadjuvant testicular androgen ablation therapy before radical prostatectomy in men with clinically localized prostate cancer. J Urol. 1996;155(4):1357-60

17. Goldenberg SL, Klotz LH, Srigley J, Jewett MA, Mador D, Fradet Y, et al. Randomized, prospective, controlled study comparing radical prostatectomy alone and neoadjuvant androgen withdrawal in the treatment of localized prostate cancer. Canadian Urologic Oncology Group. J Urol. 1996;156(3):873-7.

18. Labrie F, Cusan L, Gomez JL, Diamond P, Suburu R, Lemay M, et al. Neoadjuvant hormonal therapy: the Canadian experience. Urology. 1997:49(3A Suppl):56-64. 
19. Selli C, Montironi R, Bono A, Pagano F, Zattoni F, Manganelli A, et al. Effects of complete androgen blockade for 12 and 24 weeks on the pathological stage and resection margin status of prostate cancer. J Clin Pathol. 2002;55(7):508-13.

20. Soloway MS, Pareek K, Sharifi R, Wajsman Z, McLeod D, Wood Jr DP, et al. Neoadjuvant androgen ablation before radical prostatectomy in cT2bNxMo prostate cancer: 5-year results. J Urol. 2002;167(1):112-6.

21. Aus G, Abrahamsson PA, Ahlgren G, Hugosson J, Lundberg S, Schain M, et al. Three-month neoadjuvant hormonal therapy before radical prostatectomy: a 7-year follow-up of a randomized controlled trial. BJU Int 2002;90(6):561-6.

22. Prezioso D, Lotti T, Polito M, Montironi R. Neoadjuvant hormone treatment with leuprolide acetate depot $3.75 \mathrm{mg}$ and cyproterone acetate, before radical prostatectomy: a randomized study. Urol Int. 2004;72(3):189-95.

23. Bonney WW, Schned AR, Timberlake DS. Neoadjuvant androgen ablation for localized prostatic cancer: pathology methods, surgical end points and meta-analysis of randomized trials. J Urol. 1998;160(5):1754-60.

24. Shelley MD, Kumar S, Wilt T, Staffurth J, Coles B, Mason MD. A systematic review and meta-analysis of randomised trials of neo-adjuvant hormone therapy for localised and locally advanced prostate carcinoma. Cancer Treat Rev. 2009;35(1):9-17.

25. Stewart SB, Cheville JC, Sebo TJ, Frank I, Boorjian SA, Thompson RH, et al. Gleason grading after neoadjuvant hormonal therapy retains prognostic value for systemic progression following radical prostatectomy. Prostate Cancer Prostatic Dis. 2014;17(4):332-7.

26. Taplin ME, Montgomery B, Logothetis CJ, Bubley GJ, Richie JP, Dalkin BL, et al. Intense androgen-deprivation therapy with abiraterone acetate plus leuprolide acetate in patients with localized high-risk prostate cancer: results of a randomized phase II neoadjuvant study. J Clin Oncol. 2014;32(33):3705-15.

\section{Submit your next manuscript to BioMed Central and take full advantage of:}

- Convenient online submission

- Thorough peer review

- No space constraints or color figure charges

- Immediate publication on acceptance

- Inclusion in PubMed, CAS, Scopus and Google Scholar

- Research which is freely available for redistribution 